\title{
Peer Effects in Drug Use and Sex Among College Students
}

\author{
Greg J. Duncan, ${ }^{1,6}$ Johanne Boisjoly, ${ }^{2}$ Michael Kremer, ${ }^{3}$ Dan M. Levy, ${ }^{4}$ and Jacque Eccles ${ }^{5}$
}

Received January 13, 2004; revision received July 15, 2004; accepted August 20, 2004

Past research suggests that congregating delinquent youth increases their likelihood of problem behavior. We test for analogous peer effects in the drug use and sexual behavior of male $(n=279)$ and female $(n=435)$ college students, using data on the characteristics of first-year roommates to whom they were randomly assigned. We find that males who reported binge drinking in high school drink much more in college if assigned a roommate who also binge drank in high school than if assigned a nonbinge-drinking roommate. No such multiplier effect is observed for females, nor are multiplier effects observed for marijuana use or sexual behavior for either males or females. Students who did not engage in these behaviors in high school do not appear to be affected by their roommates' high school behavior.

KEY WORDS: alcohol drinking; substance abuse; peer effects.

A growing literature on juvenile offenders suggests that congregating deviant youth in classes, juvenile detention facilities or summer camps sparks a "contagion" process that increases the likelihood of future deviant behavior. Whether peer effects are present among middleclass youth in college is the subject of this paper. Our data are drawn from surveys of students at a large state university who were randomly assigned first-year roommates. We focus on several problem behaviors: binge drinking, marijuana use, and multiple sexual partners.

Peer effects are estimated in a variety of ways. Among students whose binge drinking, marijuana use, or sexual behavior had begun during their high school years, we estimate whether their reports of these behaviors in their second through fourth college years is greater if they were assigned first-year roommates who had engaged in these problem behaviors in high school. And for students

\footnotetext{
${ }^{1}$ School of Education and Social Policy and Institute for Policy Research, Northwestern University, Evanston, Illinois.

${ }^{2}$ Department of Sociology, University of Quebec at Rimouski, Rimouski Quebec, Canada.

${ }^{3}$ Department of Economics, Harvard University, The Brookings Institution, and NBER, Cambridge, Massachusetts.

${ }^{4}$ Mathematica Policy Research, Inc., Washington, District of Columbia.

${ }^{5}$ Department of Psychology, University of Michigan, Michigan.

${ }^{6}$ Address all correspondence to Greg J. Duncan, Institute for Policy Research, Northwestern University, 2046 Sheridan Road, Evanston, Illinois 60208; e-mail: greg-duncan@northwestern.edu.
}

who had not engaged in drug use or sex prior to college entry, we estimate whether such students might be drawn into future problem behavior if assigned roommates with a high school history of problem behavior.

All of the behaviors we investigate have potentially important consequences. Drug use and unprotected sex can compromise life chances by threatening health and, in the case of illegal drug use, risking legal sanctions (National Institute of Drug Abuse, 2002; National Institute on Alcohol Abuse and Alcoholism, 2000). And yet all are widespread on US college campuses. Defining binge drinking as five or more drinks in a row for males and four or more drinks in a row for females (Wechsler, Dowdall, Davenport, \& Rimm, 1995), Wechsler, Lee, Kuo, and Lee (2000) estimate that $44 \%$ of college students binge drank in the 2 weeks prior to responding to the 1999 College Alcohol Study. Similar rates were reported in the 1993 wave of the survey. These same surveys showed that $16 \%$ of college students reported recent marijuana use in 1999, up from 13\% in 1993 (Gledhill-Hoyt, Lee, Strote, \& Wechsler, 2000). Some $14.4 \%$ of 18-24-year-old college students reported four or more sexual partners in their lifetimes (Centers for Disease Control, 2003).

There are many theories as to why some students engage in these behaviors while others do not. Some researchers concentrate on personality difficulties such as anxiety, depression, low self-esteem, and social introversion (Kaplan, 1979; Schall, Kemeny, \& Maltzman, 1992; 
Valliant, 1995). Others examine college contexts such as institutional size and competitiveness, and residential factors such as dormitory versus fraternity or sorority residence (e.g., Wechsler et al., 2000).

Still others focus on student beliefs regarding normative behavior among their classmates. If students act, in part, to conform more closely to their perceptions of classmates' behavior and if, as appears to be the case, many students overestimate the prevalence of problem behaviors on campus, then it might be possible to affect behavior with interventions targeted on changing beliefs (Barnett, Far, Mauss, \& Miller, 1996). Many studies of drug and sex-related problem behaviors concentrate on the middle and high school periods and examine family influences such as parental monitoring and parental drinking (Reifman, Barnes, Dintcheff, Farrell, \& Uhteg, 1998).

There is ample documentation of continuities in drug and sexual behaviors across adolescence. Much larger fractions of binging than nonbinging college students reported binge drinking in high school (Wechsler et al., 2000, Table III). But while correlations in problem behavior across time are substantial, they are far from perfect: relatively few individuals are chronic binge drinkers across adolescence and into adulthood, and most eventually stop engaging in these problem behaviors altogether (Schulenberg, O'Malley, Bachman, Wadsworth, \& Johnston, 1996). However, some individuals begin to engage in these behaviors while in college and, more generally, college settings appear to be times of heightened risk for problem behaviors. Data from the Monitoring the $\mathrm{Fu}$ ture study show that while in high school, college-bound students use less of all classes of substances studied as compared to classmates not bound for college (Bachman, Wadsworth, O'Malley, Johnston, \& Schulenberg, 1997). However, after high school graduation, the increase in alcohol and marijuana use among college students exceeds that of their former classmates who are not attending college.

The focus of this paper is on how peers affect drug use and problematic sexual behavior among college students. Peer influences on problem behaviors in both early adolescence and college settings have been investigated extensively, but rarely convincingly. Many empirical studies document the fact that individuals with friends who abuse drugs are themselves more likely to abuse drugs, but fail to address problems of self-selection into peer groups (Manski, 1993; Moffitt, 2001). As long as individuals are free to choose their friends, it is possible that someone's substance abuse behavior or personal characteristics associated with substance abuse are affecting his or her choice of peer group.
Longitudinal studies have documented that individuals with friends who drink are more likely to begin drinking subsequently (e.g., Reifman et al., 1998) and to increase their drinking more rapidly (Curran, Stice, \& Chassin, 1997). While the strength of the evidence for peer impacts is stronger in longitudinal than cross-sectional studies, it is still possible that difficult-to-measure characteristics (e.g., thrill seeking) or circumstances (e.g., family problems) are leading individuals to both choose drinking peers and display unusually rapid increases in their own substance use.

A few studies of teen problem behavior have employed two-stage peer effects models in which a firststage peer group equation is estimated and then used to relate predicted peer group characteristics to teen problem behavior in the second stage equation. Evans, Oates, and Schwab (1992) estimate models of high-school completion and out-of-wedlock teen child-bearing in which their contextual variable was the SES of the student body. They identified student-body SES using characteristics of the metropolitan area in which the student resided (e.g., unemployment rate), and yet one can imagine ways in which labor market characteristics might influence teen schooling and fertility choices independently of peer influences. Norton, Lindroth, and Ennett (1998) estimate a model of peer impacts on teen alcohol and tobacco use of young adolescents, but they are forced to identify the model with parental and census-based reports of neighborhood characteristics.

What if selection of peers were beyond the control of the individual? Although no studies of substance abuse have addressed this question, a growing literature on delinquent behavior provides disturbing evidence of unintended ("iatrogenic") effects of congregating delinquent youth who do not already know one another (Dishion, McCord, \& Poulin, 1999). Bayer, Pintoff, and Pozen (2003) find that juvenile offenders released from Florida residential correctional facilities tended to commit the kinds of crimes that had been committed by their correctional-facility peers. McCord (1995) finds that assigning juvenile offenders to summer camps with the hope of reducing subsequent criminal behavior in fact had the opposite effect, when those offenders were compared with others not afforded the opportunity to attend such camps. Poulin, Dishion, and Burraston (2001) evaluated the effects of an intervention program that brought deviant teens together for sessions that emphasized prosocial goals and self-regulation. Teachers blind to treatment status reported more problem behavior 3 years later for youth in the treatment group than in a quasi-experimental control group.

If peer effects apply to substance abuse in college, then we expect that students with high school histories 
of substance abuse will abuse substances more in college as they have more contact with substance-abusing peers. National data confirm the stereotype of much more binge drinking among students living in fraternities and sororities as compared with dormitories (Wechsler et al., 2000), but here again, since such residential arrangements are chosen, one cannot conclude that drinking patterns are caused by fraternity- or sorority-based peer effects. Our paper uses the "natural experiment" of randomly assigning roommates to get around the confounding effects of residential choice.

Hypothesis 1: Individuals who abuse drugs or engage in sexual intercourse prior to college entry will exhibit greater frequency of these behaviors in college if assigned a roommate who also engaged in these behaviors in high school than if assigned a roommate who did not.

Note that this peer effects hypothesis applies to youth who binged, used marijuana, or engaged in sex prior to entering college. Whether the subsequent problem behavior of students entering college without these experiences is influenced by the prior experiences of their college roommates is less clear. Social learning or pressures to conform might lead innocent youth to adopt the problem behaviors of their roommates. On the other hand, a bingedrinking roommate may annoy a nondrinking roommate by making sleep or study more difficult. Illegal drug use may have a discouraging effect if it increases the risk that innocent roommates might be arrested.

Hypothesis 2: Whether individuals who do not abuse drugs or engage in sexual intercourse prior to college entry are affected by college roommates' high school behavior is ambiguous and depends on the strength of encouraging and discouraging factors.

Kremer and Levy (2002), using data from randomly assigned roommates at a large state university, find that males assigned to roommates who reported drinking in the year prior to entering college had one quarter-point lower GPA than those assigned to nondrinking roommates. Furthermore, they find that the effect of a frequent drinking roommate on GPA was larger for frequent drinkers than for nondrinkers and persisted over time, which they take to support their preference/habit formation model rather than their disruption model. Because they did not have data on student drinking during college, they could not confirm that lower grades were associated with more frequent binge drinking.

Our own paper shifts the focus of the Kremer and Levy work from college academic outcomes to college problem behaviors-specifically binge drinking, mari- juana use, and multiple sex partners. Furthermore, the results on binge drinking will shed light on the mechanism behind the effects of roommate drinking on academic performance observed by Kremer and Levy.

\section{METHODS}

\section{Data Sources}

Our data are taken from students entering a large, academically strong state university in the fall of 1998, 1999, and 2000. The university's housing office provided information on each student's housing application and housing assignment. High school grades, socioeconomic information, and some behavioral data on students were gathered from the Cooperative Institutional Research Program's (CIRP) Entering Student Survey, an annual survey of the American higher-education system that was started in 1966 by the American Council on Education and is now conducted jointly by the Council and the University of California, Los Angeles. In the case of the particular university in our study, entering students filled in the survey at an orientation session occurring before classes begin. Although a few students may have met their roommates first, the large majority of students filled out this survey over the summer, before meeting their roommates.

Questions about drug use and sexual behavior in high school and at the time of the interview were asked in a survey we administered to students who entered the university in the fall of 1998, 1999, and 2000 and were randomly assigned roommates. The timing of our survey (winter/spring of 2002) provides us with data when students were more than halfway through their second, third, and fourth years; the average number of years between college entry and responding to the follow-up survey was 2.4 years. The survey was administered via the Internet with a telephone follow-up to maximize response rates.

\section{Measures}

\section{Dependent Variables}

The follow-up survey provides measures of binge drinking at the time of the survey and whether the student binge drank at all during high school. In keeping with standard research practice (Wechsler et al., 1995), we defined binge drinking differently for males and females-five or more drinks in a row for males and four or more in a row for females. High school binge drinking was presumed to take place if the respondent reported that the first time he 
or she drank the requisite number of drinks was "before college." Current binge drinking is measured as times per month in response to the respective question "Over the past 2 weeks, on how many occasions have you had [four if female/five if male] or more drinks in a row?" Responses are converted to a monthly amount by multiplying by 2.15 .

We used information provided by the answers to these questions to classify respondents and their roommates into the following categories: i) neither binge drank in high school; ii) the respondent did not binge drink in high school but the roommate did; iii) the respondent binge drank in high school but the roommate did not; iv) both binge drank in high school; and v) roommatedrinking data are not ascertained owing to case or item nonresponse. The dependent variable is the frequency of the respondent's binge drinking at the time of the followup survey.

Similar questions regarding marijuana use provide measures of any marijuana use in high school and monthly frequency of marijuana use "during the last 12 months." Our measure of current sexual behavior is based on responses to the questions "During the last 12 months, with how many partners do you estimate you have had sexual intercourse?" Sex in high school is defined by a "before college" response to the question "When did you have sexual intercourse for the first time?"

\section{Control Variables}

CIRP measures used as control variables in our regressions include both self and roommate responses to questions about: (i) years of father's education; (ii) years of mother's education; (iii) high school grade point average; and (iv) family income.

We also controlled for respondents' and roommates' high school test scores. Since some students took only the SAT, others took only the ACT, and some took both, a common admissions test score measure was needed as an academic background variable. We therefore standardized test scores using the ACT scale based on concordance tables (published by both ACT, Inc. and the College Board), which are used by many admissions offices around the country (including the admissions office of the university used in this study).

Race and ethnicity were asked in the single question: "Are you (mark all that apply): White/Caucasian, African American/Black, American Indian, Asian American/ Asian, Mexican American/Chicano, Puerto Rican, Other Latino, Other." We coded as "white" respondents who marked only the first category, "black" respondents who marked only the second category, and "Asian" respondents who marked only the fourth category. For our "Hispanic" designation we included respondents who gave Mexican American/Chicano, Puerto Rican, or Other Latino and no other response. All respondents marking more than one category, marking American Indian, or marking "Other" fall into our "Other" category.

Of all entering students in the 1998 and 1999 cohorts, about $90 \%$ completed the CIRP survey (corresponding response-rate data for the 2000 cohort are not available). Of the 10,268 CIRP respondents, 2232 opted to live in enrichment residence halls, 2029 requested a roommate, 724 requested living alone during their first year, 4134 failed to meet the lottery deadline, and 42 otherwiseeligible students were not assigned a roommate, leaving 1107 students eligible for our lottery sample.

To avoid missing data and other complications of multiple roommates, we concentrated our analysis on the 990 individuals who were randomly assigned a single roommate. The follow-up survey response rate among this sample was $72 \%$ and produced an analysis sample of 714. Response rates were considerably higher for females (76\%) than males (67\%). Missing data on individual survey items reduced this case count further. The bulk of nonrespondents could not be located; only $1.8 \%$ of all nonrespondents were successfully contacted but refused to participate in the study.

\section{Roommate Assignment}

Since our identification strategy takes advantage of the roommate assignment process, it is worth reviewing this process. Students who met the lottery deadline were assigned rooms randomly, conditional on gender and four basic housing preferences: environment (substance-free housing, nonsmoking roommate, do not mind smoking roommate, and smoker), room type (single, double, triple occupancy, and other), geographic area of campus, and gender composition of hall and corridor. For some of these preferences, students could indicate a first, second, and third choice.

For students participating in the lottery, roommate assignment should be random, conditional on gender, and basic housing preferences. We call a combination of gender and housing preferences a cell. All of our regression analyses control for the student's combination of first choices of housing preferences (using the "absorb" features of Stata and SAS's Proc. GLM). In effect, this amounts to a fixed-effects regression in which peer effect estimates are based only on within-preference-cell variability.

To verify that the housing assignment process was indeed random within cells, we first spoke with housing officers to understand how the assignment process worked 
and the computer software used to make the assignments. We then reviewed the documentation of the computer software used for the 1997 and 1998 entering cohorts and checked that it truly randomized within cells. Finally, using techniques discussed more fully in Kremer and Levy (2002), we verified that, controlling for all housing preference choices, initial roommates' background characteristics were not significantly correlated.

It is important to note that when we use the term "roommate" we are referring to the roommate initially assigned to the student when entering the university. If a student changed roommates we do not use the information on the new roommates because this would raise the possibility of self-selection and possibly bias our results. For example, a student might well eventually switch to a roommate who is more similar or compatible than the initial roommate. If this is the case, and we used actual roommate (instead of initial roommate) information in our regressions, our peer-effect estimates could reflect self-selection. University policy does not allow roommate changes during the first 6 weeks of classes except for extreme cases such as those involving violence, and strongly discourages any roommate changes during the first year. Less than $5 \%$ of students switch roommates during their first term, but $82 \%$ had switched roommates by the beginning of their second years.

\section{RESULTS}

\section{Descriptive Statistics}

Table I shows descriptive statistics for our dependent variables. Binge drinking and marijuana use are fairly widespread at this university. About half of the respondents reported at least some binge drinking in the 2 weeks prior to completing the follow-up survey. As a point of comparison, Wechsler et al. (2000) report that $44.1 \%$ of students reported binge drinking in the 2 weeks prior to their 1999 survey.

Including students with zeroes, current binge drinking averages 3.9 times per month for males and 2.8 times per month for females. Frequencies are about twice as high among students who engage in at least some binge drinking. As shown in the last column of Table I, females report significantly less binge drinking than do males.

Marijuana use is somewhat less pervasive than binge drinking, although it is still reported by at least one third of both male and female students at the time of the follow-up survey. The average monthly frequency of marijuana use is considerably lower for females than males, and lower than binge drinking for both groups.

The distribution of responses to the question on number of current sexual partners is shown at the bottom of Table I. A little over one third of both males and females report no sexual intercourse in the 12 months preceding the follow-up interview, and an additional one third reported sex with only one partner. Roughly one fifth of both groups report two to three partners. The average number of partners does not differ significantly between males and females.

Data on control variables are presented in Table II. Roughly one third of the roommates of follow-up survey respondents did not respond to the survey. For the remainder, roughly similar fractions fall into the various combinations of respondent/roommate binge drinking in high school. Regarding marijuana use, the modal group

Table I. Summary Statistics of Binge Drinking, Marijuana Use and Sexual Behavior

\begin{tabular}{|c|c|c|c|c|c|c|c|}
\hline & \multicolumn{3}{|c|}{ Male $(n=279)$} & \multicolumn{3}{|c|}{ Female $(n=435)$} & \multirow{2}{*}{$\begin{array}{l}P \text { value of } t \text { - or chi-square } \\
\text { test on gender differences }\end{array}$} \\
\hline & Mean & Std. dev. & $\%$ zero & Mean & Std. dev. & $\%$ zero & \\
\hline $\begin{array}{l}\text { Current binge drinking (\# of times } \\
\text { per month) }\end{array}$ & 3.86 & 5.550 & 48.0 & 2.81 & 4.160 & 53.1 & 0.005 \\
\hline $\begin{array}{l}\text { Current use of marijuana (\# of times } \\
\text { per month in the last } 12 \text { months) }\end{array}$ & 2.45 & 6.170 & 52.0 & 1.18 & 3.540 & 60.1 & 0.001 \\
\hline \multirow{2}{*}{$\begin{array}{l}\text { Current number of sex partners (\# in } \\
\text { the last } 12 \text { months) }\end{array}$} & 1.23 & 1.430 & & 1.07 & 1.260 & & 0.120 \\
\hline & & & Distribution & & & Distribution & \\
\hline $\begin{array}{l}\text { No sexual intercourse in the last } \\
12 \text { months }\end{array}$ & & & 36.7 & & & 38.4 & \\
\hline 1 person & & & 35.6 & & & 38.6 & \\
\hline 2-3 people & & & 20.4 & & & 18.6 & 0.536 \\
\hline 4-5 people & & & 6.6 & & & 4.0 & \\
\hline 6-12 people & & & 0.7 & & & 0.5 & \\
\hline Total & & & 100.0 & & & 100.0 & \\
\hline
\end{tabular}


Table II. Summary Statistics of Individual and Roommate Characteristics

\begin{tabular}{|c|c|c|c|c|}
\hline & \multicolumn{4}{|c|}{ Respondents to the follow-up survey ${ }^{a}$} \\
\hline & \multicolumn{2}{|c|}{ Males } & \multicolumn{2}{|c|}{ Females } \\
\hline & Mean & Std. dev. & Mean & Std. dev. \\
\hline \multicolumn{5}{|l|}{ Respondent and roommate high school behavior } \\
\hline Neither respondent nor roommate binge drank in high school & .143 & .351 & .230 & .421 \\
\hline Respondent but not roommate binge drank in high school & .118 & .324 & .133 & .340 \\
\hline Roommate but not respondent binge drank in high school & .118 & .324 & .133 & .340 \\
\hline Both respondent and roommate binge drank in high school & .190 & .393 & .159 & .366 \\
\hline Neither respondent nor roommate had marijuana in high school & .224 & .418 & .348 & .477 \\
\hline Respondent but not roommate had marijuana in high school & .141 & .348 & .109 & .312 \\
\hline Roommate but not respondent had marijuana in high school & .141 & .348 & .109 & .312 \\
\hline Both respondent and roommate had marijuana in high school & .090 & .287 & .095 & .294 \\
\hline Neither respondent nor roommate had sex in high school & .269 & .444 & .301 & .459 \\
\hline Respondent but not roommate had sex in high school & .100 & .301 & .124 & .330 \\
\hline Roommate but not respondent had sex in high school & .100 & .301 & .124 & .330 \\
\hline Both respondent and roommate had sex in high school & .115 & .319 & .092 & .289 \\
\hline Roommate nonresponse to follow-up survey & .394 & .490 & .317 & .466 \\
\hline \multicolumn{5}{|l|}{ Respondent characteristics (all gathered in entering student survey) } \\
\hline Black & .014 & .119 & .021 & .143 \\
\hline Asian & .050 & .219 & .097 & .296 \\
\hline Hispanic & .025 & .157 & .039 & .194 \\
\hline Other & .057 & .233 & .034 & .183 \\
\hline Father's education & 16.552 & 1.819 & 16.391 & 2.007 \\
\hline Mother's education & 16.055 & 1.907 & 15.728 & 2.164 \\
\hline High school grade point average & 3.781 & .246 & 3.782 & .259 \\
\hline Test scores (ACT scale) & 28.952 & 2.499 & 27.744 & 2.647 \\
\hline Family income (in tens of thousands) & 12.128 & 5.930 & 11.924 & 6.286 \\
\hline \multicolumn{5}{|l|}{ Roommate characteristics (all gathered in entering student survey) } \\
\hline Non-white roommate & .151 & .358 & .161 & .368 \\
\hline Roommate's father's education & 16.581 & 1.751 & 16.445 & 1.975 \\
\hline Roommate's mother's education & 16.016 & 1.826 & 15.848 & 2.059 \\
\hline Roommate's high school grade point average & 3.765 & .262 & 3.774 & .261 \\
\hline Roommate's test scores (ACT scale) & 28.729 & 2.608 & 27.578 & 2.726 \\
\hline Roommate's average family income (in tens of thousands) & $\begin{array}{c}13.176 \\
n=279\end{array}$ & 6.335 & $\begin{array}{c}12.333 \\
n=435\end{array}$ & 6.499 \\
\hline
\end{tabular}

${ }^{a}$ All randomly assigned one roommate.

consisted of respondent/roommate pairs in which both had never had marijuana in high school. In the case of sexual behavior, the modal group consisted of respondent/roommate pairs in which both were virgins in high school.

The remaining rows of Table II show the affluent nature of the sample, with high paternal and maternal education and family incomes averaging more than $\$ 100,000$. Test scores and high school grade-point averages are high. Relatively few of the students were from minority groups.

\section{Peer Effects in Binge Drinking}

Regression models of current binge drinking are reported in Table III. The "respondent but not roommate binge drank in high school" category is used as the reference group, so coefficients on the included variables show regression-adjusted differences in college binge drinking relative to this group. In order to test whether peer effects exist for those who binge drank in high school (hypothesis 1), the key explanatory variable of interest is "both binge drank in high school."

In all cases, we present separate models for males and females and run what amount to fixed-effects regressions with controls for all combinations of first housing preferences. Since we were unable to secure software that simultaneously: (i) provided a Tobit regression procedure to handle the substantial number of "zero" responses in our dependent variables (Table II); (ii) enabled us to use multiple imputation procedures for missing data on our independent variables; and (iii) enabled us to adjust 
Table III. Individual and Roommate Characteristics as Predictors of Current Binge Drinking (Number of Times Per Month)

\begin{tabular}{|c|c|c|c|c|c|c|c|c|}
\hline & \multicolumn{4}{|c|}{ OLS regression $^{a}$} & \multicolumn{4}{|c|}{ Tobit regression ${ }^{b}$} \\
\hline & \multicolumn{2}{|c|}{ Male } & \multicolumn{2}{|c|}{ Female } & \multicolumn{2}{|c|}{ Male } & \multicolumn{2}{|c|}{ Female } \\
\hline \multicolumn{9}{|l|}{ Respondent and roommate high school behavior } \\
\hline $\begin{array}{l}\text { Neither respondent nor roommate binge } \\
\text { drank in high school }\end{array}$ & $-2.227^{*}$ & 1.224 & $-3.447^{* *}$ & .604 & $-2.637^{* *}$ & .641 & $-2.463^{* *}$ & .335 \\
\hline $\begin{array}{l}\text { Roommate but not respondent binge drank } \\
\text { in high school }\end{array}$ & $-1.893^{*}$ & 1.067 & $-3.365^{* *}$ & .720 & $-3.142^{* *}$ & .417 & $-2.147^{* *}$ & .280 \\
\hline \multicolumn{9}{|l|}{$\begin{array}{l}\text { Respondent but not roommate binge drank } \\
\text { in high school (reference) }\end{array}$} \\
\hline $\begin{array}{l}\text { Both respondent and roommate binge } \\
\text { drank in high school }\end{array}$ & $3.830^{* *}$ & 1.042 & -.424 & .886 & $2.582^{* *}$ & 1.121 & -.126 & .528 \\
\hline $\begin{array}{l}\text { Roommate nonresponse to follow-up } \\
\text { survey }\end{array}$ & & & & & .066 & .778 & $-1.271^{* *}$ & .410 \\
\hline \multicolumn{9}{|c|}{ Respondent characteristics (all gathered in entering student survey) } \\
\hline Black & -.985 & 2.481 & .847 & 1.482 & -.744 & 2.072 & .214 & 1.445 \\
\hline Asian & -.382 & 1.926 & .661 & .685 & -1.368 & .954 & .223 & .669 \\
\hline Hispanic & -1.392 & 2.075 & -.521 & 1.057 & 1.497 & 2.145 & -.681 & .736 \\
\hline Other & -1.791 & 1.606 & 1.548 & 1.180 & -.195 & 1.110 & 1.825 & 1.248 \\
\hline Father's education & -.213 & .221 & $.298^{* *}$ & .121 & -.143 & .176 & .149 & .105 \\
\hline Mother's education & .196 & .219 & $-.380^{* *}$ & .105 & -.003 & .164 & $-.243^{* *}$ & .090 \\
\hline High school grade point average & -1.243 & 1.526 & $-1.978^{* *}$ & .820 & -1.379 & 1.136 & -1.183 & .706 \\
\hline Test scores (ACT scale) & .075 & .141 & $.155^{*}$ & .082 & -.062 & .116 & .034 & .071 \\
\hline Family income (in thousands) & $-.200^{* *}$ & .063 & .058 & .037 & -.034 & .049 & $.078^{* * *}$ & .030 \\
\hline \multicolumn{9}{|c|}{ Roommate characteristics (all gathered in entering student survey) } \\
\hline Non-white roommate & -.154 & .945 & .220 & .557 & -.780 & .699 & .454 & .524 \\
\hline Roommate's father's education & -.167 & .208 & -.077 & .117 & -.166 & .171 & .024 & .102 \\
\hline Roommate's mother's education & -.093 & .203 & -.048 & .106 & -.057 & .160 & .012 & .090 \\
\hline $\begin{array}{l}\text { Roommate's high school grade point } \\
\text { average }\end{array}$ & -.567 & 1.328 & -.760 & .790 & .591 & 1.058 & .216 & .669 \\
\hline Roommate's test scores (ACT scale) & -.081 & .131 & -.005 & .079 & -.059 & .109 & -.059 & .068 \\
\hline Roommate's family income (in thousands) & $\begin{array}{c}-.097^{*} \\
N=279\end{array}$ & .055 & $\begin{array}{c}.007 \\
N=435\end{array}$ & .033 & $\begin{array}{l}-.054 \\
N=271\end{array}$ & .044 & $\begin{array}{c}-.054 \\
N=426\end{array}$ & .027 \\
\hline
\end{tabular}

Note. All regressions include controls for housing preferences, cohort and test taken; values not shown.

${ }^{a}$ With control for all combinations of 1st preferences and missing data imputation, but no adjustment for roommate clustering.

${ }^{b}$ Coefficients shown are marginal effects. Tobit regressions include controls for a restricted number of combinations of 1 st preferences. Missing values assigned to the mean and controlled for by missing value indicators; values not shown.

${ }^{*} p \leq .10 .{ }^{* *} p \leq .05$.

with Huber-White methods for the lack of independence caused by roommate clustering, we present both OLS as well as Tobit models. Our SAS-based OLS models incorporate multiple imputation for missing data but no HuberWhite clustering adjustment, while our Stata-based Tobit coefficients (expressed as marginal effects) incorporate Huber-White clustering adjustments but use missing data dummies to handle missing data.

High school binge drinking is a powerful predictor of college binge drinking. Both male and female respondents entering college with a history of binge drinking report much more frequent binge drinking at the time of the follow-up interview than respondents entering college without a history of binge drinking. In the case of respondents assigned nondrinking roommates, respondents who binge drank in high school averaged 2.2-3.4 more binge drinking episodes per month at the time of the follow-up survey than respondents who did not drink in high school, as reflected in the coefficient of the variable "neither respondent binge drank in high school" across the various regression specifications.

Peer effects in binge drinking is present if college drinking for students who entered college with a history of heavy drinking is magnified when those students are assigned roommates who had similar high-school histories (Hypothesis 1). Since "respondent but not roommate binge drank in high school" is the reference category, the coefficient on "both respondent and roommate binge drank in high school" reflects our estimate of peer effects. The first column, on the basis of OLS estimation 
for males, shows a large and statistically significant deviant peer effect-almost four times more binge drinking episodes per month. The magnitude of the analogous coefficient based on the Tobit specification for males is smaller (2.58) but still statistically significant. But for females, the coefficient is insignificant and even has an unexpected negative sign (on both the OLS and Tobit specifications).

Are nondrinking students susceptible to peer influence if matched with drinking roommates? Here the relevant coefficients are on the "roommate but not respondent binge drank in high school" and "neither respondent nor roommate binge drank in high school" categories, which contrast nondrinkers who were and were not paired up with drinking roommates. Since supplemental calcula- tions showed that these two coefficients are insignificantly different from one another in all cases, Table III provides no evidence of peer effects for nondrinkers.

\section{Peer Effects in Marijuana Use and Sexual Behavior}

In some respects, the patterns of marijuana use parallel those of binge drinking (Table IV). Marijuana use in high school and college are highly correlated, male respondents who had not used marijuana in high school were, if anything, turned off rather than turned on by marijuana-using roommates, and there is no evidence of peer effects for females. But a key difference is that there is no evidence of multiplier effects for marijuana use

Table IV. Individual and Roommate Predictors of Current Use of Marijuana (Number of Times Per Month in the Last 12 Months)

\begin{tabular}{|c|c|c|c|c|c|c|c|c|}
\hline & \multicolumn{4}{|c|}{ OLS regression $^{a}$} & \multicolumn{4}{|c|}{ Tobit regression $^{b}$} \\
\hline & \multicolumn{2}{|c|}{ Male } & \multicolumn{2}{|c|}{ Female } & \multicolumn{2}{|c|}{ Male } & \multicolumn{2}{|c|}{ Female } \\
\hline \multicolumn{9}{|l|}{ Respondent and roommate high school behavior } \\
\hline $\begin{array}{l}\text { Neither respondent nor roommate used } \\
\text { marijuana in high school }\end{array}$ & $-3.672^{* *}$ & .978 & $-2.028^{* *}$ & .759 & $-2.366^{* *}$ & .458 & $-1.443^{* *}$ & .253 \\
\hline $\begin{array}{l}\text { Roommate but not respondent used } \\
\text { marijuana in high school }\end{array}$ & $-3.899^{* *}$ & 1.085 & $-1.934^{* *}$ & .742 & $-2.886^{* *}$ & .333 & $-.811^{* *}$ & .202 \\
\hline \multicolumn{9}{|l|}{$\begin{array}{l}\text { Respondent but not roommate used } \\
\text { marijuana in high school (reference) }\end{array}$} \\
\hline $\begin{array}{l}\text { Both respondent and roommate used } \\
\text { marijuana in high school }\end{array}$ & .092 & 1.560 & -.190 & 1.029 & -.105 & .847 & .095 & .393 \\
\hline $\begin{array}{l}\text { Roommate nonresponse to follow-up } \\
\text { survey }\end{array}$ & & & & & $-1.572^{* *}$ & .565 & $-.597^{* *}$ & .257 \\
\hline Black & -1.436 & 2.609 & -.598 & 1.555 & -.807 & 1.525 & -.061 & .789 \\
\hline Asian & .090 & 1.615 & .279 & .686 & -.515 & .975 & -.150 & .354 \\
\hline Hispanic & -.419 & 2.120 & -1.039 & 1.073 & -.798 & 1.053 & $-.906^{* *}$ & .203 \\
\hline Other & -.005 & 1.688 & -.894 & 1.186 & 2.571 & 1.573 & $-.605^{*}$ & .322 \\
\hline Father's education & -.055 & .242 & $.222^{*}$ & .125 & -.138 & .149 & $.110^{*}$ & .066 \\
\hline Mother's education & -.008 & .221 & -.130 & .103 & -.129 & .145 & -.063 & .057 \\
\hline High school grade point average & $-2.697^{*}$ & 1.575 & -.696 & .834 & -1.265 & 1.008 & -.485 & .427 \\
\hline Test scores (ACT scale) & .117 & .152 & .028 & .095 & $.263^{* *}$ & .104 & .025 & .046 \\
\hline Family income (in thousands) & .074 & .066 & -.037 & .037 & $.080^{*}$ & .042 & -.027 & .019 \\
\hline \multicolumn{9}{|c|}{ Roommate characteristics (all gathered in entering student survey) } \\
\hline Non-white roommate & .614 & .978 & -.398 & .553 & -.216 & .666 & -.203 & .283 \\
\hline Roommate's father's education & -.193 & .215 & .027 & .119 & -.078 & .146 & .009 & .064 \\
\hline Roommate's mother's education & -.133 & .211 & .075 & .107 & -.009 & .133 & $.094^{*}$ & .057 \\
\hline $\begin{array}{l}\text { Roommate's high school grade point } \\
\text { average }\end{array}$ & -.520 & 1.372 & -.796 & .807 & -.504 & .867 & -.004 & .412 \\
\hline Roommate's family income (in thousands) & $\begin{array}{c}.101^{*} \\
N=279\end{array}$ & .057 & $\begin{array}{c}.003 \\
N=435\end{array}$ & .035 & $\begin{array}{c}-.001 \\
N=277\end{array}$ & .037 & $\begin{array}{c}-.003 \\
N=431\end{array}$ & .017 \\
\hline
\end{tabular}

Note. All regressions include controls for housing preferences, cohort and test taken; values not shown.

${ }^{a}$ With control for all combinations of 1 st preferences and missing data imputation, but no adjustment for roommate clustering.

${ }^{b}$ Coefficients shown are marginal effects. Tobit regressions include controls for a restricted number of combinations of 1 st preferences. Missing values assigned to the mean and controlled for by missing value indicators; values not shown.

${ }^{*} p \leq .10$. ${ }^{* *} p \leq .05$. 
Table V. Individual and Roommate Predictors of Current Number of Sexual Partners (Nos. in the Last 12 Months)

\begin{tabular}{|c|c|c|c|c|c|c|c|c|}
\hline \multirow[b]{3}{*}{$\begin{array}{l}\text { Neither respondent nor roommate had sex in } \\
\text { high school }\end{array}$} & \multicolumn{4}{|c|}{ OLS regression $^{a}$} & \multicolumn{4}{|c|}{ Tobit regression $^{b}$} \\
\hline & \multicolumn{2}{|c|}{ Male } & \multicolumn{2}{|c|}{ Female } & \multicolumn{2}{|c|}{ Male } & \multicolumn{2}{|c|}{ Female } \\
\hline & $-.756^{* *}$ & .282 & $-1.168^{* *}$ & .191 & $-.893^{* *}$ & .204 & $-.903^{* *}$ & .137 \\
\hline $\begin{array}{l}\text { Roommate but not respondent had sex in high } \\
\text { school }\end{array}$ & -.433 & .346 & $-.969^{* *}$ & .215 & $-.742^{* *}$ & .204 & $-.710^{* *}$ & .124 \\
\hline \multicolumn{9}{|l|}{$\begin{array}{l}\text { Respondent but not roommate had sex in high } \\
\text { school (reference) }\end{array}$} \\
\hline $\begin{array}{l}\text { Both respondent and roommate had sex in high } \\
\text { school }\end{array}$ & $.842^{* *}$ & .399 & .355 & .251 & .235 & .337 & .278 & .240 \\
\hline Roommate nonresponse to follow-up survey & & & & & $-.473^{*}$ & .244 & $-.542^{* *}$ & .143 \\
\hline \multicolumn{9}{|c|}{ Respondent characteristics (all gathered in entering student survey) } \\
\hline Black & -.049 & .680 & -.073 & .479 & -.347 & .612 & -.303 & .369 \\
\hline Asian & -.383 & .423 & -.325 & .209 & $-.817^{* *}$ & .218 & $-.452^{* *}$ & .158 \\
\hline Hispanic & -.720 & .555 & .334 & .325 & .155 & .539 & .357 & .323 \\
\hline Other & -.317 & .452 & .031 & .370 & .428 & .375 & .233 & .320 \\
\hline Father's education & -.012 & .060 & -.021 & .039 & -.025 & .049 & $-.068^{*}$ & .033 \\
\hline Mother's education & $-.109^{*}$ & .057 & .010 & .032 & $-.077^{*}$ & .047 & .026 & .031 \\
\hline High school grade point average & .074 & .401 & -.363 & .261 & -.084 & .339 & $-.511^{* *}$ & .232 \\
\hline Test scores (ACT scale) & $-.061^{*}$ & .037 & $.043^{*}$ & .025 & $-.071^{* *}$ & .034 & $.041^{*}$ & .023 \\
\hline Family income (in thousands) & .005 & .016 & -.011 & .012 & .016 & .014 & -.001 & .010 \\
\hline \multicolumn{9}{|c|}{ Roommate characteristics (all gathered in entering student survey) } \\
\hline Non-white roommate & -.075 & .260 & -.145 & .168 & $-.412^{* *}$ & .190 & $-.239^{*}$ & .141 \\
\hline Roommate's father's education & .009 & .055 & -.012 & .038 & -.025 & .048 & -.018 & .033 \\
\hline Roommate's mother's education & -.032 & .051 & .037 & .033 & -.015 & .044 & .013 & .030 \\
\hline Roommate's high school grade point average & -.394 & .358 & .020 & .255 & $-.578^{*}$ & .308 & -.052 & .222 \\
\hline Roommate's test scores (ACT scale) & .003 & .035 & -.013 & .024 & .015 & .031 & .001 & .022 \\
\hline Roommate's family income (in thousands) & $\begin{array}{l}-.018 \\
N=279\end{array}$ & .014 & $\begin{array}{c}.000 \\
N=435\end{array}$ & .011 & $\begin{array}{l}-.007 \\
N=275\end{array}$ & .013 & $\begin{array}{l}-.001 \\
N=425\end{array}$ & .010 \\
\hline
\end{tabular}

Note. All regressions include control for housing preferences, cohort, test taken; values not shown. Missing values assigned to the mean and controlled for by missing value indicators; values not shown. Standard errors adjusted for room clustering using Huber-White robust estimations except for Tobit model.

${ }^{a}$ With control for all combinations of 1 st preferences and missing data imputation, but no adjustment for roommate clustering.

${ }^{b}$ Coefficients shown are marginal effects. Tobit regressions include controls for a restricted number of combinations of 1 st preferences. Missing values assigned to the mean and controlled for by missing value indicators; values not shown.

${ }^{*} p \leq .10 .{ }^{* *} p \leq .05$

among males who entered college having used marijuana in high school. Individuals in this group who were paired with marijuana-using roommates reported no significantly greater use of marijuana at the time of the follow-up survey than those paired with nonmarijuana-using roommates.

There is no conclusive evidence of peer effects in the sexual behavior outcomes either (Table V). Both males and females who lost their virginity in high school report more sexual partners at the time of the follow-up survey than high-school virgins. And while the nonvirgins who are paired with nonvirgins report a somewhat larger number of sexual partners than nonvirgins paired with virgin roommates; the difference is only statistically significant for males under the OLS specification. In the case of sex coupled with binge drinking, both binge drinking and sex in high school boost the reported frequency of this combination.

\section{DISCUSSION}

Intervention research on juvenile offending is uncovering disturbing evidence that congregating offending youth into treatment groups may spur a kind of "deviancy training" that increases rather than reduces future problem behavior (Dishion et al., 1999). Whether a similar process might be taking place in college dormitories is the subject of this paper.

We find important but rather selective evidence of the dangers of grouping college students who exhibited 
problem behavior in high school. Pairing up young men who binge drank in high school appears to promote binge drinking in college. No such multiplier effect is observed for females, nor are multiplier effects observed for marijuana use or sexual behavior for either males or females.

Theory is more ambivalent about the consequences of roommate pairings for first-year college students with no prior history of problem behavior. We uncovered no evidence that being paired with a roommate with problematic high school behavior had any effect on a student's own problematic behavior in college.

Our evidence on peer effects on drinking behavior raises important questions about why males who binge drink in high school are so vulnerable to roommate influences. Our interviews provide some data on the nature of social interactions and compatibility with first-year roommates, as well as beliefs regarding normative behavior. We intend to explore possible mediational processes in our future work. We also plan to use additional data to explore whether the observed peer effects on drinking behavior are also present in the first year of college and whether these effects grow or diminish over time.

Also of interest is why peer effects are observed for binge drinking but neither marijuana nor sexual behavior. A possible methodological reason is that our threshold for high school drinking (i.e., binge amounts) is considerably higher than for marijuana use (i.e., any such use before college) or sex (i.e., any sexual intercourse before college). We investigated this by grouping roommates according to whether each reported any drinking during high school. When we ran regressions that were similar to those presented in Table III, the multiplier effects disappeared. Men who reported any drinking in high school were no more likely to binge drink in college if assigned a roommate who drank at all in high-school than not. Thus, the deviant peer effect appears to apply only to students who had drunk heavily while in high school. We lacked information on the extent of marijuana use or sexual behavior in high school.

A final methodological issue is whether the sex difference in the definition of binge drinking (five drinks in a row for males and four for females) might account for the differential peer impacts estimated for males and females. Since our survey followed the prevailing practice for defining thresholds for binge drinking, we are unable to assess the sensitivity of the results to this difference.

Our results suggest that, for the most part, students, parents, and college administrators need not fear that roommate assignments will promote problem behavior during college. Indeed, our other work with these data suggests that shuffling the roommate deck and pairing students who did not know one another prior to college en- try may promote social understanding (Boisjoly, Duncan, Kremer, Levy, \& Eccles, 2004). An important exception is that pairing young men with drinking problems may aggravate those problems. Despite the logistical difficulties in identifying entering students with binge drinking histories, our results suggest substantial benefits to ensuring that binge-drinking young men do not room together in their first college year.

\section{ACKNOWLEDGMENTS}

Financial support from the W.T. Grant Foundation, the John D. and Catherine T. Arthur Foundation, and the NICHD Child and Family Well-Being Research Network (2 U01 HD30947-07) is gratefully acknowledged. We thank Sean McCabe, Carol Boyd, and William Zeller for their contributions in the early stages of this research; Brian Madden, Deanna Maida, and Bessie Wilkerson for research assistance; and John Schulenberg and members of the Executive Session on Deviant Peer Influences for their comments.

\section{REFERENCES}

Bachman, J., Wadsworth, K., O’Malley, P., Johnston, L., \& Schulenberg, J. (1997). Smoking, drinking and drug use in young adulthood: The impacts of new freedoms and new responsibilities. Mahwah, $\mathrm{NJ}$ : Erlbaum.

Bayer, P., Pintoff, R., \& Pozen, D. (2003). Building criminal capital behind bars: Social learning in juvenile corrections (Working Paper). Yale, CT: Yale University, Economics Department.

Barnett, L., Far, J., Mauss, A., \& Miller, J. (1996). Changing perceptions of peer norms as a drinking reduction program for college students. Journal of Alcohol and Drug Education, 41, 3962.

Boisjoly, J., Duncan, G., Kremer, M., Levy, D., \& Eccles, J. (2004). Empathy or antipathy? The impact of diversity (Working paper). Institute for Policy Research, Northwestern University.

Centers for Disease Control. (2003). Youth online comprehensive results. Youth Risk Behavior Surveillance System. Retrieved from http://apps.nccd.cdc.gov/yrbss/QuestYearTable.asp?ByVar=CI\& $\mathrm{cat}=4 \&$ quest $=$ Q60\&loc $=\mathrm{XX} \&$ year $=2003$.

Curran, P., Stice, E., \& Chassin, L. (1997). The relation between adolescent alcohol use and peer alcohol use: A longitudinal random coefficients model. Journal of Consulting and Clinical Psychology, $65,130-140$.

Dishion, T., McCord, J., \& Poulin, F. (1999). When interventions harm: Peer groups and problem behavior. American Psychologist, 54, 755-764.

Evans, W. N., Oates, W. E., \& Schwab, R. M. (1992). Measuring peer group effects: A study of teenage behavior. Journal of Political Economy, 100, 966-991.

Gledhill-Hoyt, J., Lee, H., Strote, J., \& Wechsler, H. (2000). Increased use of marijuana and other illicit drugs at US colleges in the 1990s: Results of three national surveys. Addiction, 95, 1655-1667.

Kaplan, M. (1979). Patterns of alcoholic beverage use among college students. Journal of Alcohol and Drug Education, 24, 26-40.

Kremer, M., \& Levy, D. (2002). Peer effect from alcohol use among college students. Mimeo, Harvard University. 
Manski, C. (1993). Identification of endogenous social effects: The reflection problem. Review of Economic Studies, 60, 531-542.

McCord, J. (1995). Some unintended consequences of summer camps. Paper presented at the Society for Research on Child Development, Indianapolis, March 30th to April 2nd, 1995.

Moffitt, R. A. (2001). Policy interventions, low-level equilibria and social interactions. In S. Durlauf \& P. Young (Eds.), Social dynamics. Cambridge, MA: MIT Press.

National Institute of Drug Abuse. (2002). NIDA Research ReportMarijuana Abuse (NIH Publication No. 02-3859). National Institute of Health.

National Institute on Alcohol Abuse and Alcoholism. (2000). Highlights from the Tenth Special Report to Congress. Alcohol Research and Health, 24.

Norton, E., Lindroth, R., \& Ennett, S. (1998). Controlling for the endogeneity of peer substance use on adolescent alcohol and tobacco use. Health Economics, 7, 439-453.

Poulin, F., Dishion, T., \& Barraston, B. (2001). 3-Year iatrogenic effects associated with aggregating high-risk adolescents in cognitivebehavioral preventive interventions. Applied Developmental Science, 5, 214-224.
Reifman, A., Barnes, G., Dintcheff, B., Farrell, M., \& Uhteg, L. (1998). Parental and peer influences on the onset of heavier drinking among adolescents. Journal of Studies on Alcohol, 59, 311318.

Schall, M., Kemeny, A., \& Maltzman, I. (1992). Factors associated with alcohol use in university students. Journal of Studies on Alcohol, $53,122-136$.

Schulenberg, J., O’Malley, P., Bachman, J., Wadsworth, K., \& Johnston, L. (1996). Getting drunk and growing up: Trajectories of frequent binge drinking during the transition to young adulthood. Journal of Studies on Alcohol, 57, 289-304.

Valliant, P. (1995). Personality, peer influence and use of alcohol and drugs by first-year university students. Psychological Reports, 77, 401-402.

Wechsler, H., Lee, J., Kuo, M., \& Lee, H. (2000). College binge drinking in the 1990s: A continuing problem. Journal of American College Health, 48, 199-210.

Wechsler, H., Dowdall, G., Davenport, A., \& Rimm, E. (1995). A gender-specific definition of binge drinking among college students. American Journal of Public Health, 85, 982985 . 